\title{
Cyclin-like F-box protein plays a role in growth and development of the three model species
} Medicago truncatula, Lotus japonicus, and Arabidopsis thaliana

\author{
This article was published in the following Dove Press journal: \\ Research and Reports in Biology \\ 4 August 2015 \\ Number of times this article has been viewed
}

Irina Boycheva'

Valya Vassileva ${ }^{2}$

Miglena Revalska'

Grigor Zehirov²

Anelia lantcheva'

'Department of Functional Genetics Legumes, ${ }^{2}$ AgroBiolnstitute,

Department of Plant Stress Molecular Biology, Institute of Plant Physiology and Genetics, Sofia, Bulgaria
Correspondence: Anelia lantcheva Department of Functional Genetics Legumes, AgroBiolnstitute, Bul Dragan

Tzankov 8, Sofia II64, Bulgaria

$\mathrm{Tel}+35929635413$

Fax +359 29635408

Email aneliaiancheva@abi.bg

\begin{abstract}
In eukaryotes, F-box proteins are one of the main components of the SCF complex that belongs to the family of ubiquitin E3 ligases, which catalyze protein ubiquitination and maintain the balance between protein synthesis and degradation. In the present study, we clarified the role and function of the gene encoding cyclin-like F-box protein from Medicago truncatula using transgenic plants of the model species M. truncatula, Lotus japonicas, and Arabidopsis thaliana generated by Agrobacterium-mediated transformation. Morphological and transcriptional analyses combined with flow cytometry and histochemistry demonstrated the participation of this protein in many aspects of plant growth and development, including processes of indirect somatic embryogenesis and symbiotic nodulation. The cyclin-like F-box gene showed expression in all plant organs and tissues comprised of actively dividing cells. The observed variations in root and hypocotyl growth, leaf and silique development, ploidy levels, and leaf parameters in the obtained transgenic lines demonstrated the effects of this gene on organ development. Furthermore, knockdown of cyclin-like F-box led to accumulation of higher levels of the $\mathrm{G} 2 / \mathrm{M}$ transition-specific gene cyclin B1:1 (CYCB1:1), suggesting its possible role in cell cycle control. Together, the collected data suggest a similar role of the cyclin-like F-box protein in the three model species, providing evidence for the functional conservation of the studied gene.
\end{abstract}

Keywords: cyclin-like F-box, model legumes, Arabidopsis thaliana, plant growth, plant development, cell cycle

\section{Introduction}

Control of protein turnover is a crucial post-translational regulatory mechanism that allows rapid responses and adaptation of plants to internal and external signals generated by changing environmental conditions. The well controlled balance between protein synthesis and degradation is essential in maintaining and improving cellular homeostasis and survival. Plant cells contain multiple proteolytic systems to carry out their degradation processes. In general, nonfunctional and misfolded proteins are targeted for selective degradation via the ubiquitin-proteasome system, which is the major intracellular proteolysis machinery in eukaryotic cells (UPS; 26S proteasome). ${ }^{1}$

Protein ubiquitination requires the sequential action of a multi-enzymatic system: ubiquitin-activating enzyme (E1) activates and transfers ubiquitin to ubiquitinconjugating enzyme (E2) before reaching the final enzyme, ubiquitin protein ligase E3, which recognizes and catalyzes the covalent attachment of activated ubiquitin to 
a specific sequence on the target protein. ${ }^{2}$ The attachment is mediated by formation of an isopeptide bond between the lys- $\varepsilon$-amino group (lys 48) of the target protein and the last amino acid of ubiquitin (glycine 76). ${ }^{3}$ The E3 ubiquitin ligases comprise a diverse family of proteins in plants, representing approximately more than 1,400 genes in the genome of Arabidopsis thaliana. ${ }^{3}$ The SCF (SKP1 [S-phase-kinaseassociated protein 1], Cullin-1, F-box protein) complex is the largest family of E3 ubiquitin protein ligases, composed of four protein subunits, each represented by a different number of amino acid residues: $\mathrm{Cul}$ (776 residues), F-box protein (430-1,000 residues), Skp1 (163 residues), and Rbx1 (108 residues). ${ }^{4}$ The elongated structure of $\mathrm{Cul}$ serves as a scaffold that organizes the other proteins in the complex. The N-terminal region of the Cul subunit is composed of 415 amino acids, whereas the $\mathrm{C}$-terminal domain contains 360 amino acids. The $\mathrm{N}$-terminal region binds with Skp1 and F-box protein, whereas the C-terminal domain is associated with Rbx1 protein. ${ }^{4}$ F-box adaptor protein is composed of at least eight functional motifs: F-box motif, zink fingers, leucine zipper, ring fingers, TPR (tetratricopeptide repeats), WD (Trp-Asp repeats), proline-rich regions, and leucine-rich repeats, and confers the specificity of the SCF complex by selectively recruiting target proteins by a protein-protein interaction domain. ${ }^{5}$

The genome of $A$. thaliana contains one CUL1 gene, 21 genes coding ASK (A. thaliana SKP1-like) proteins, and approximately $700 F$-Box $(F B X)$ genes. ${ }^{6-8}$ The number of $F$-box genes is different between species. Twenty genes are found in Saccharomyces cerevisiae, 33 in Drosophila melanogaster, and 69 in the human genome, with a much higher number in plants. ${ }^{910}$ Currently, 897 F-box genes are identified in A. thaliana, 971 in Oryza sativa, 425 in Populus trichocarpa, and 156 in Vitis vinifera. ${ }^{8,11}$

In the model plant $A$. thaliana, less than $5 \%$ of the F-box proteins have been investigated and functionally characterized. These proteins are involved in regulation of multiple developmental processes, including leaf senescence and branching, flower development, phytohormone signaling, circadian rhythms, and defense responses. ${ }^{12-20}$

The present study investigated the function of the gene encoding cyclin-like F-box protein from Medicago truncatula in three model species, ie, M. truncatula, Lotus japonicas, and A. thaliana. Transcriptional reporter plants carrying cyclin like F-box endogenous promoter fused to $\beta$-glucuronidase (GUS) and green fluorescent protein (GFP) reporter genes were generated for the three model species. Stable transgenic plants with overexpression (OE) and knockdown of the gene were obtained for $A$. thaliana. Histochemical and fluorescent analyses revealed expression of cyclin-like F-box in different plant tissues and organs, showing involvement of this protein in many aspects of plant growth and development. Morphological and transcriptional analyses, combined with flow cytometry and histochemistry, demonstrated its similar role in the three model species, providing evidence of the functional significance of the investigated cyclin-like F-box in plant growth.

\section{Materials and methods Construction of expression vectors for genetic transformation}

The recombinant plasmids were generated using the Gateway ${ }^{\circledR}$ cloning system (Invitrogen Life Technologies, Inc., http://www.lifetechnologies.com). The entry clones were constructed by inserting the promoter sequences of the F-box gene (MT2G007220, Plaza 2.5) into the PDONRP4P1R donor vector and the open reading frame of the gene into the pDONR221 donor vector. Expression clones were generated by recombining the entry clones carrying the promoter fragments into the $p E X-K 7 S N F m 14 G W$ (promoter NLS-GUS/GFP) destination vector possessing the neomycin phosphotransferase (nptII) gene as a selection marker for transgenic plants. The cyclin-like F-box entry clone was transferred into $p K 7 W G 2$ and $p K 7 F W G 2$ destination vectors (C-terminal translational GFP fusion) for OE, under the control of the CaMV $35 S$ promoter and the nptII gene for plant selection. ${ }^{21}$

The RNA interference (RNAi) method, which is a powerful reverse genetic tool for studying gene function in M. truncatula, was used to silence cyclin-like F-box expression in a sequence-specific manner. ${ }^{22}$ As the RNAi mechanism is based on formation of double-stranded RNA, Xwin Razor software was used in silico to predict the region of the gene with high silencing capacity, which is optimal for synthesis of double-stranded RNAs. To identify the required sequence of the gene, simple sequence analysis of target mRNAs was used, and the specificity was evaluated by a single BLASTn search against the database for M. truncatula (ie, the Medicago truncatula Genome Project). Xwin Razor can therefore predict a region of copy DNA of the gene, optimal for synthesis of mRNA. The section of the RNA transcript was selected, which is optimal for synthesis of small double-stranded RNA. In order to create a cyclinlike F-box RNAi construct, a $p K 7 G W I W G 2 D(I I)$ hairpin RNA expression vector was used and 148 bp from mRNA corresponding to nucleotide positions $960-1,108$ bp of the 
open reading frame of Medicago truncatula (Mt) cyclin-like F-box gene and 956-1,108 bp of the open reading frame of the Arabidopsis ortholog AT1G10780 gene.

The resulting constructs were introduced into the Agrobacterium tumefaciens strain C58C1, which was maintained on YEB nutrient medium solidified with agar (1.5\%) and supplemented with rifampicin $100 \mathrm{mg} / \mathrm{L}$, spectinomycin $100 \mathrm{mg} / \mathrm{L}$, and gentamicin $50 \mathrm{mg} / \mathrm{L}$.

The list of primers used for construction of the vectors is provided in Table $\mathrm{S} 1$.

\section{Plant material, growth conditions, and genetic transformation}

Transcriptional reporter plants from the three model species were obtained by $A$. tumefaciens-mediated transformation with a plasmid carrying the endogenous promoter of the $F$-box gene from $M$. truncatula fused to the reporter genes GUS and GFP (pMtrF-box:GUS:GFP).

\section{Medicago truncatula}

Seeds from the highly regenerable genotype $M$. truncatula cv. "Jemalong $2 \mathrm{HA}$ " were surface-sterilized with a $6 \%(\mathrm{v} / \mathrm{v})$ solution of sodium hypochlorite (commercial bleach) for 15 minutes, rinsed at least three times with sterile distilled water, and germinated on Murashige and Skoog (MS) basal medium. ${ }^{23,24}$ The germinated seedlings were then propagated by cuttings. In vitro plant materials were grown in Magenta boxes $(60 \times 60 \times 96 \mathrm{~mm}$, Sigma-Aldrich $)$ in a growth chamber at $24^{\circ} \mathrm{C}$, with a 16 -hour photoperiod and a light intensity of $30 \mu \mathrm{mol} \mathrm{m} \mathrm{m}^{-2} \mathrm{~s}^{-1}$. Seven-day-old seedlings from transgenic plants were inoculated with a bacterial suspension containing approximately $2.10^{8}$ cells per $\mathrm{mL}$ of Sinorhizobium meliloti 1021.

\section{Composition of plant medium for regeneration/transformation}

Leaf and petiole explants collected from 35-day-old in vitro plants were used as explants for genetic transformation. M. truncatula transcriptional reporter plants were produced by application of a combined protocol. ${ }^{25-27}$ Leaf and petiole explants were wounded using a scalpel blade and precultivated on a solid callus induction medium (CIM) known as $\mathrm{SHab}$ (SH macronutrients, micronutrients and vitamins plus $5 \mathrm{mg} / \mathrm{L}$ auxin 2,4-dichlorophenoxyacetic acid [2.4-D] and $1 \mathrm{mg} / \mathrm{L}$ 6-benzyloaminopurine [BAP]) for 2 days in darkness. Pretreated explants were inoculated with bacterial suspension $\left(\mathrm{OD}_{600} 0.5\right)$ for 1 hour on a horizontal shaker at $100 \mathrm{rpm}$. The transformed plant material was cocultivated for a further 48 hours, then transferred for 2 weeks to selective SHab medium with kanamycin $50 \mathrm{mg} / \mathrm{L}$ and carbenicillin $400 \mathrm{mg} / \mathrm{L}$ for selection of transformed tissue and removal of Agrobacterium. After appearance of callus along the edge of the wounded areas, the explants were transferred to CIM (MS macronutrients, micronutrients, and vitamins plus zeatin $2 \mathrm{mg} / \mathrm{L}$ and 2.4-D $1 \mathrm{mg} / \mathrm{L}$ ) with fresh kanamycin and carbenicillin at the same concentrations for another 2 weeks in order to finish process of callus initiation. After forming clearly visible callus tissue, the explants were transferred to 09-03 medium (MS macronutrients, micronutrients plus BAP $0.9 \mathrm{mg} / \mathrm{L}$ and $\alpha$-naphthaleneacetic acid $0.3 \mathrm{mg} / \mathrm{L}$, in order to form green embryo zones), without the selective agent kanamycin for 2 weeks. This step without selective pressure was applied for easier embryo formation and subsequent development of embryo structures on MS1 medium (BAP $0.05 \mathrm{mg} / \mathrm{L}$ and casein hydrolysate $250 \mathrm{mg} / \mathrm{L}$ ) for two passages of 20-25 days. With the appearance of embryo structures in the cotyledonary stage, the plant material was transferred to selective MS medium containing kanamycin $50 \mathrm{mg} / \mathrm{L}$ for a roothold. The putative transgenic rooted plantlets were cultivated on selective MS basal medium supplemented with kanamycin $50 \mathrm{mg} / \mathrm{L}$. After sampling for analyses, they were transferred to soil and grown in a greenhouse for production of seed.

\section{Lotus japonicus}

Seeds of L. japonicus ecotype B-129 Gifu, a kind gift from Dr Hiroshi Kouchi, were scarified with sandpaper and surface-sterilized with $70 \%$ (v/v) ethanol for 30 seconds, followed by $0.1 \%(\mathrm{v} / \mathrm{v})$ mercury chloride for 8 minutes, then rinsed at least three times with sterile distilled water, and germinated on MS basal medium. ${ }^{24}$ The germinated seedlings were then propagated by cuttings. Leaf explants collected from 30-40-day-old in vitro plants were used for Agrobacterium-mediated transformation. In vitro plant material was grown in Magenta boxes $(60 \times 60 \times 96 \mathrm{~mm})$ in a growth chamber at $24^{\circ} \mathrm{C}$, with a 16 -hour photoperiod and light intensity of $30 \mu \mathrm{mol} \mathrm{m} \mathrm{m}^{-2} \mathrm{~s}^{-1}$. Seven-day-old seedlings from transgenic plants were inoculated with a bacterial suspension containing approximately $2.10^{8}$ cells per $\mathrm{mL}$ of Mesorhizobium loti MAFF 303099.

\section{Composition of plant regeneration/ transformation medium}

CIM was based on B5 solid medium containing 2.4-D $4 \mathrm{mg} / \mathrm{L}$, kinetin $0.8 \mathrm{mg} / \mathrm{L}$, adenine (6-aminopurine, SigmaAldrich) $1 \mathrm{mg} / \mathrm{L}, 500 \mathrm{mg} / \mathrm{L}$ casein hydrolysate, myoinositol 
$500 \mathrm{mg} / \mathrm{L}, 3 \%$ sucrose $(\mathrm{w} / \mathrm{v})$, and $0.7 \%(\mathrm{w} / \mathrm{v})$ phyto agar (P 1003, http://www.duchefa.com), and embryo induction medium was based on MS medium supplemented with BAP $0.9 \mathrm{mg} / \mathrm{L}, \alpha$-naphthaleneacetic acid $0.3 \mathrm{mg} / \mathrm{L}, 3 \%$ sucrose $(\mathrm{w} / \mathrm{v})$, and $0.7 \%(\mathrm{w} / \mathrm{v})$ phyto agar as described elsewhere. ${ }^{27,28}$ The embryo development medium for L. japonicus was based on B5 medium supplemented with BAP $0.2 \mathrm{mg} / \mathrm{L}, 3 \%$ sucrose $(\mathrm{w} / \mathrm{v})$, and $0.7 \%(\mathrm{w} / \mathrm{v})$ phyto agar. Basal MS was used for embryo conversion and rooting medium.

\section{Transformation procedure}

Leaf and petiole explants detached from in vitro plants were wounded with a scalpel blade and pretreated on CIM for 48 hours before inoculation with bacterial suspension. Explants were inoculated with bacterial suspension with an optical density of $\mathrm{OD}_{600}=0.3$ for 1 hour and cocultivated for 2 days on solid CIM without selective antibiotics. After the cocultivation period, the explants were transferred to solid medium supplemented with kanamycin $50 \mathrm{mg} / \mathrm{L}$ for selection and carbenicillin $400 \mathrm{mg} / \mathrm{L}$ to remove bacterial infection and promote induction of callus tissue. The selective medium was refreshed every 20 days. After 60 days, embryogenic calli were transferred to embryo induction medium free of selective pressure for 25 days. The first green zones on calli appeared after 10-15 days, subsequently growing and becoming clusters of closely packed thick globular embryos. Further development of the embryos was continued on embryo development medium as described above for 2-3 passages (20 days each). Dark green globular embryos slowly developed and formed cotyledonary leaves after at least two passages (40 days). Kanamycin selection was maintained during the embryo development stage and continued at the same concentration on medium for embryo conversion and rooting.

\section{Arabidopsis thaliana}

Wild-type $A$. thaliana ecotype Columbia-0 plants were used to obtain transgenic plants by the floral dip method. ${ }^{29}$ Seeds collected from the primary transformants were sterilized with $70 \%$ ethanol for 2 minutes, followed by 12 minutes of incubation in commercial bleach, and rinsed several times with sterile distilled water. The seeds were then plated on square plates containing agar-solidified MS medium (20 g/L sucrose, $0.43 \mathrm{~g} / \mathrm{L} 2-(N$-morpholino)ethanesulfonic acid, 0.8\% plant tissue culture agar, and kanamycin $50 \mathrm{mg} / \mathrm{L}$ ). This strategy was followed for obtaining homozygous $\mathrm{T}_{3}$ plants. ${ }^{24}$ In vitro plant material was adapted in soil and grown in a greenhouse under long-day conditions (16 hours light/8 hour dark) at $21^{\circ} \mathrm{C}$. Root tips meristem was synchronized on the base of the previously described method. ${ }^{30}$ Initially, the seeds were grown on MS medium for 5 days on Prosep nylon mesh and then transferred to MS medium containing $1 \mathrm{mM}$ hydroxyurea (Sigma-Aldrich).

\section{Light microscopy}

Leaves from 3-week-old plants were cleared in 96\% ethanol until chlorophyll was completely removed, and then mounted in lactic acid on glass slides for 24 hours. The samples were observed under a Carl Zeiss Axio upright microscope. Leaf area was determined as the mean sum of 12 individual leaf blade areas as measured on scanned images. To determine mean epidermal cell area $\left(\mu \mathrm{m}^{2}\right)$, epidermal cells were measured at two different zones on each leaf. Epidermal cell number was estimated as the means of 12 leaves. Leaf area, cell size, and cell number were analyzed using Image J 1.41 software.

\section{Fluorescence and confocal microscopy}

Images of plant segments expressing GFP were collected using an SZX7 fluorescence stereomicroscope with a DP73 digital camera (Olympus) fitted with MGFPA filters (excitation 460-490 nm and emission 510-550 nm). Fluorescence imaging of roots was performed using an Axiovert100M confocal laser scanning microscope with software package LSM510 version 3.2 (Zeiss). For excitation of GFP, the $488 \mathrm{~nm}$ line of an argon laser was used.

\section{Quantitative RT-PCR analysis}

Gene expression studies were carried out using total RNA extracted from seedlings of wild type, OE, and RNAi lines and total RNA extracted from root tips of the OE, RNAi, and control lines (20 root tips per time point of each repeat; $1 \mathrm{~mm}$ in size). RNA was isolated with the RNeasy plant mini kit (Qiagen) and copy DNA was prepared via reverse transcription with the First Strand cDNA synthesis kit (Fermentas). Relative expression levels were analyzed in triplicate using a 7,300 real-time polymerase chain reaction (PCR) system (Applied Biosystems). The expression levels of two endogenous reference genes, ACT and UBQ10, were used for data normalization. The sequences of primers used for quantitative reverse transcription (RT)-PCR analysis are given in Table S1.

\section{GUS activity assay}

For histochemical GUS staining, samples from in vitro and greenhouse-grown plants from the three model species were incubated in $90 \%$ acetone for 30 minutes at $4^{\circ} \mathrm{C}$, then washed in phosphate buffer at room temperature and incubated in GUS solution (10 mL, 5 mg 5-bromo-4-chloro-3-indolyl- $\beta$-d- 
glucuronide dissolved in $50 \mu \mathrm{L}$ of formamide; $5 \mathrm{~mL}, 100 \mathrm{mM}$ sodium phosphate buffer (pH 7.0); $200 \mu \mathrm{L}, 0.5 \mathrm{M} \mathrm{Na}_{2}$ EDTA; $10 \mu \mathrm{L}$, Triton $\mathrm{X}-100 ; 1 \mathrm{~mL}, 1 \mathrm{mM} \mathrm{K}{ }_{4} \mathrm{Fe}(\mathrm{CN})_{6} .3 \mathrm{H}_{2} \mathrm{O} ; 1 \mathrm{~mL}$, $1 \mathrm{mM} \mathrm{K} \mathrm{K}_{3} \mathrm{Fe}(\mathrm{CN})_{6} ; 2 \mathrm{~mL}$, methanol and supplemented with $240 \mu \mathrm{L}$ of $\mathrm{H}_{2} \mathrm{O}$ ) at $37^{\circ} \mathrm{C}$ overnight.

\section{Flow cytometry}

Leaves from 3-week-old $A$. thaliana in vitro wild-type and transgenic plants were chopped with a razor blade and placed in $200 \mu \mathrm{L}$ of CyStain UV Precise nuclei extraction buffer. The DNA was stained by adding $800 \mu \mathrm{L}$ of staining buffer (Partec). Measurements were carried out with a flow cytometer (CyFlo, Partec) and the samples were analyzed with CXP Analysis software (Partec). For each technical repeat, three or more leaves were analyzed.

\section{Root and leaf measurements}

Root lengths were measured 5 days after seed germination and assessed every 24 hours over 3 consecutive days. The lengths of at least 20 roots of the selected OE and RNAi lines and wild-type plants were measured for each data set. Leaves collected from the first external circle of the rosette were scanned and used for measurement of subsequent indicators: length and width of silique, length and width of leaf blade, and petiole length. The images were analyzed using ImageJ 1.41 software.

\section{Statistical analysis}

All experiments were repeated three times and triplicate assays were performed for each experimental data set. The data were analyzed using repeated-measures analysis of variance via Statistical Package for the Social Sciences version 11.5 software (SPSS Inc., Chicago, IL, USA). $P$-values $<0.05$ were considered to be statistically significant. The results are expressed as the mean \pm standard deviation.

\section{Results}

Plants from M. truncatula and L. japonicus containing promoter-reporter gene constructs were screened for the presence of the nptII marker gene. Homozygous transgenic plants ( $\mathrm{T}_{3}$ generation) of $A$. thaliana were obtained by kanamycin selection. Confirmed transgenic plants were used for further analyses.

\section{Histochemical localization of GUS} reporter activity in transgenic $M$. truncatula, L. japonicus, and A. thaliana plants

GUS reporter activity in transgenic $M$. truncatula plants under the control of the endogenous F-box promoter ( $p$ F-box:GUS:GFP) of the investigated gene (MT2G007220 PLAZA 2,5) was established in different stages of indirect somatic embryogenesis: globule (Figure 1A), torpedo (Figure 1B), and cotyledon (Figure 1C) in young leaves (Figure 1D) and developing leaflets (Figure 1E), pistils (Figure 1F), and primary roots and lateral root initials (Figure 1G). GFP fluorescence was detected in the trichomes of young in vitro leaves (Figure S1B).

In L. japonicas, GUS activity was observed in globular embryos (Figure 2A) induced on explants during indirect somatic embryogenesis, in primary root and lateral root branches (Figure 2B), in vascular tissue of root nodules (Figure 2C), the petiole (Figure 2D), the base of the pistil
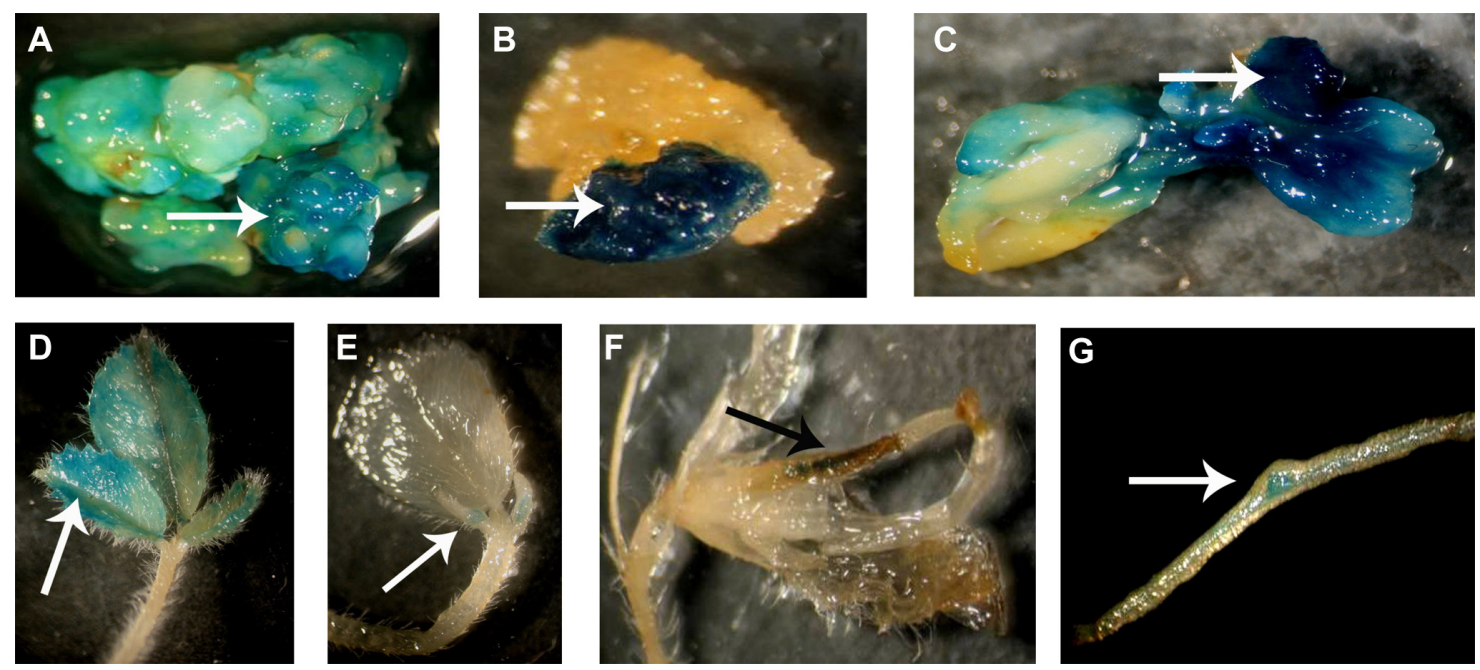

Figure I Expression of the marker gene for glucuronidase activity in transgenic (pF-box:GUS:GFP) Medicago truncatula plants.

Notes: (A-C) Stages of somatic embryogenesis, (D) young leaf, (E) developing leaflets, $(\mathbf{F})$ flower, and $(\mathbf{G})$ primary root with initial of secondary root branching. 

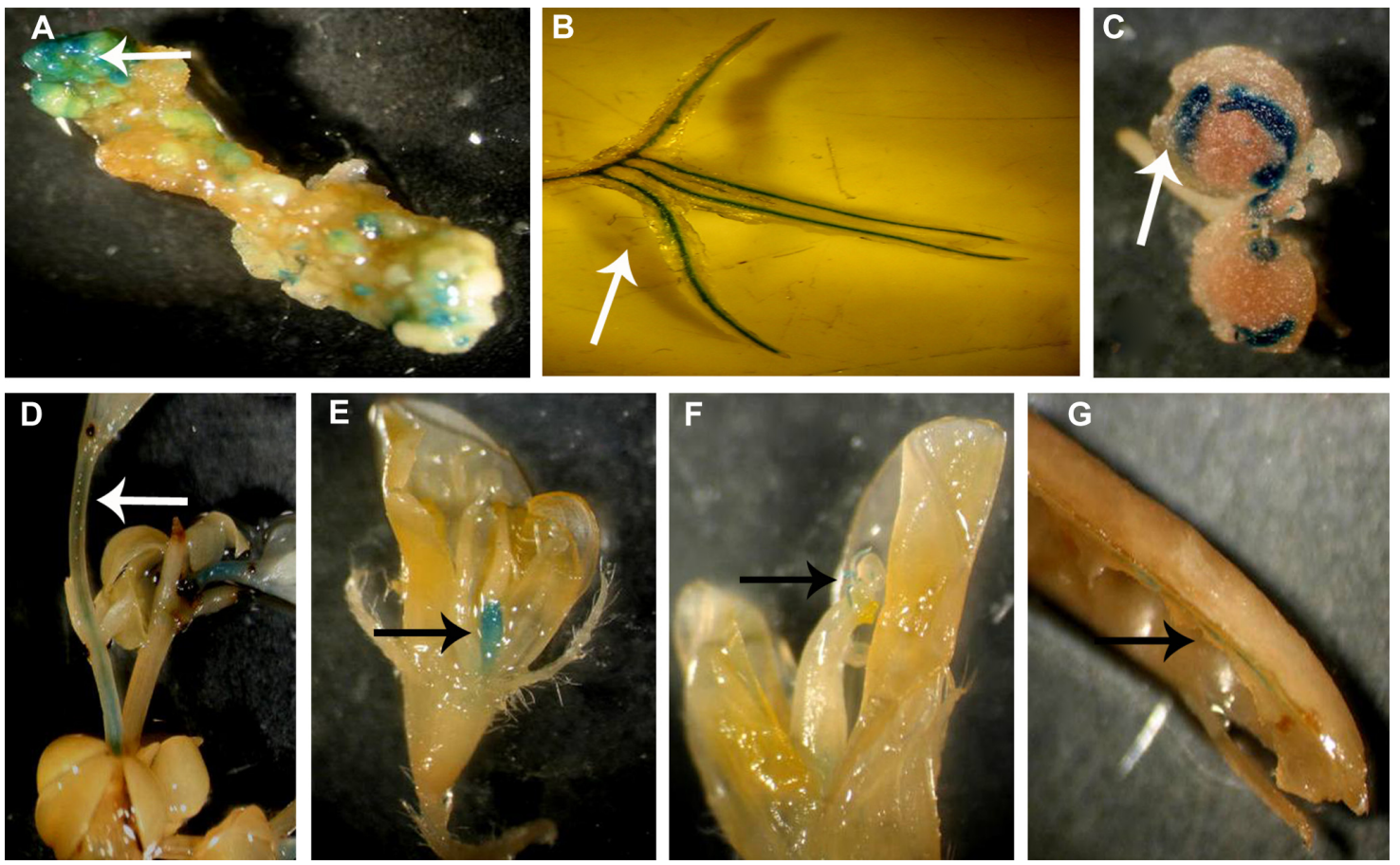

Figure 2 Expression of the marker gene for glucuronidase activity in transgenic ( $p F$-box:GUS:GFP) Lotus japonicas plants Notes: (A) Petiole explant with induced globular embryos, (B) primary root, (C) nodules, (D) petiole, (E) pistil, (F) anthers, and (G) pod.

(Figure 2E), the anthers of the stamen (Figure 2F), and in the vascular tissue of the pod (Figure $2 \mathrm{G}$ ). The GFP reporter gene was expressed in nodule tissue (Figure S1A).

Expression of the GUS gene driven by the MtF-box promoter was investigated in A. thaliana transcriptional reporter plants. Strong GUS activity was detected in cotyledons of seedlings (Figure 3A) and true leaves (Figure 3B) and in the shoot apex (Figure 3C). Signal was found in the vasculature (Figure 3D) of the primary roots and in the lateral root primordia and root tips (Figure $3 \mathrm{E}-\mathrm{G}$ ) and inter-vein regions of leaves, but no expression was detected in the stem (Figure 3H). In addition, GUS expression was seen in floral buds in carpels (Figure 3I) and petals (Figure 3J).

Confocal imaging revealed GFP fluorescence in the root vascular cylinder, as F-box expression was strongest in the root meristem zone (Figure $3 \mathrm{~K}$ and $\mathrm{L}$ ) and lateral root primordia (Figure $3 \mathrm{M}$ and $\mathrm{N}$ ). In the outgrowing lateral roots, expression was localized predominantly in the vasculature, giving the same localization pattern observed for the primary root (Figure 3O).

\section{Expression analysis of $A$. thaliana lines with OE or knockdown of cyclin-like F-box}

F-box was heterologically expressed in $A$. thaliana and its expression level was evaluated by quantitative RT-PCR in three selected homozygous lines with OE (Figure 4A) and knockdown (RNAi) of the gene (Figure 4B). It was shown that the F-box transcript level was increased 8.0 times in the OE1 and OE2 lines when compared with the control, and was significantly higher in the OE3 line than in the first two lines (Figure 4A). Lines RNAi 4/2, RNAi 6/1, and RNAi 6/2 were examined for F-box endogenous expression. The transcript level of F-box was decreased up to 2.0-4.0 times in the RNAi 4/2 and RNAi 6/2 lines when compared with the control line (Figure 4B). All further analyses in A. thaliana were performed with the OE1, RNAi 4/2, and RNAi 6/2 lines.

\section{Morphometric analyses}

\section{Root growth}

Statistical analysis of root growth dynamics for OE1 showed a significantly $(P \leq 0.05)$ lower root growth rate in the OE1 line at 48 hours when compared with the wild-type line (Figure 4C). In contrast, root length increased faster in the RNAi $6 / 2$ line than in control roots at 24 hours $(P \leq 0.001)$, 48 hours ( $P \leq 0.0001)$, and 72 hours ( $P \leq 0.0001$; Figure $4 \mathrm{D})$. Higher root growth rates were recorded in the RNAi 4/2 line at 24 hours $(P \leq 0.01)$ and 48 hours $(P \leq 0.05$; Figure $4 \mathrm{D})$.

\section{Hypocotyl growth}

Hypocotyl elongation was significantly $(P \leq 0.001)$ reduced in the RNAi $6 / 2$ line on day 7 , but was significantly $(P \leq 0.0001)$ higher on day 10 when compared with the 

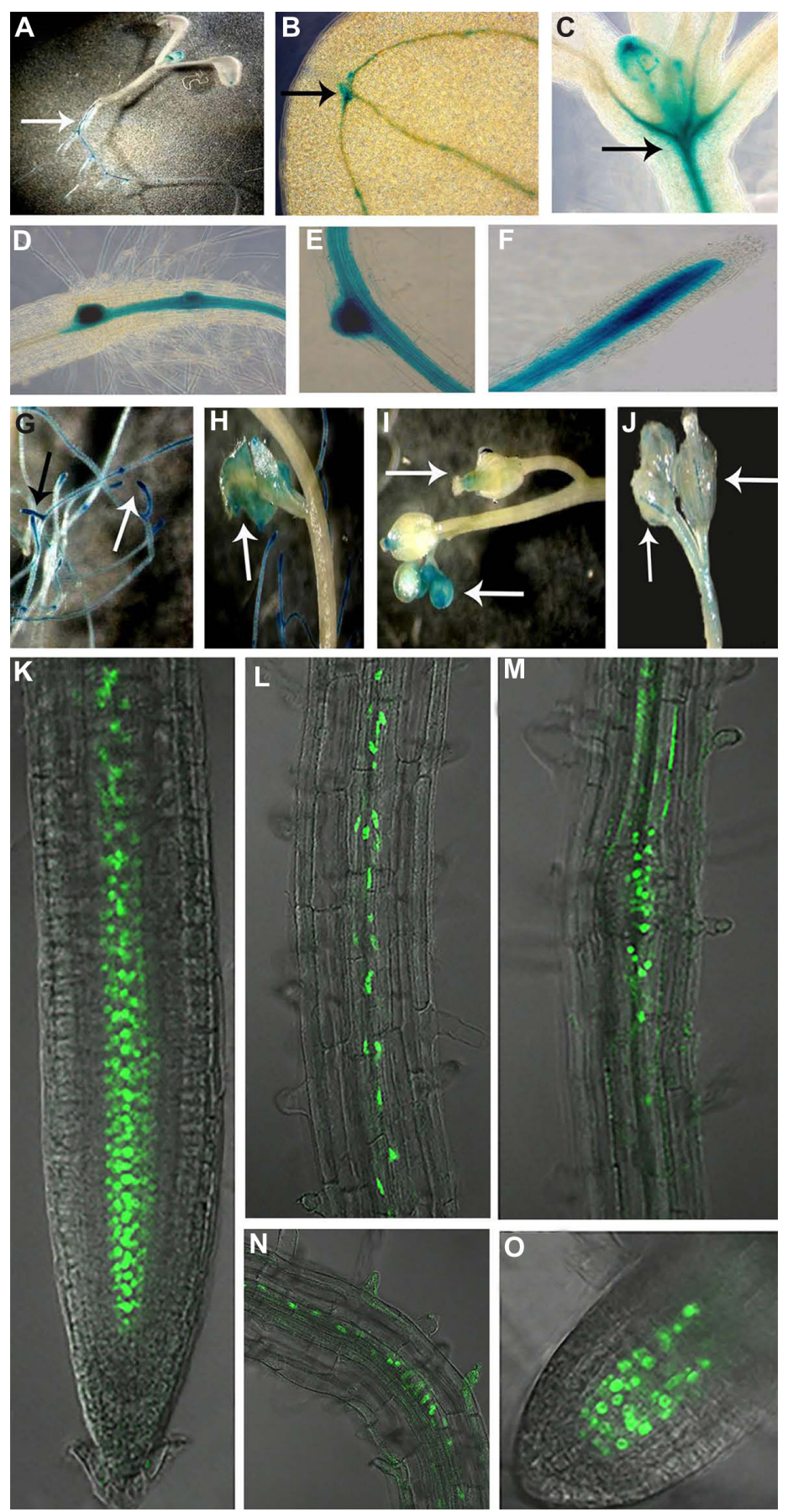

Figure 3 Expression pattern of GUS and GFP reporter genes in transgenic (pF-box:GUS:GFP) Arabidopsis thaliana plants.

Notes: (A) Seven-day-old seedling, (B) cotyledon from a 7-day-old seedling, (C) shoot apical meristem, (D) primary root with lateral root primordium, (E) primary root with lateral root branch, $(\mathbf{F})$ primary root tip, $(\mathbf{G})$ root system with secondary roots from a 20-day-old seedling, $(\mathbf{H})$ true leaf from a 20 -day-old seedling, $(\mathbf{I})$ floral buds, (J) young flowers, ( $\mathbf{K}$ and $\mathbf{L})$ primary root, $(\mathbf{M}$ and $\mathbf{N})$ lateral root primordia, and $(\mathbf{O})$ emerging lateral root.

control line (Figure 4F). No significant difference was found in hypocotyl growth of $\mathrm{OE}$ lines compared with wild-type at days 7 and 10 (Figure 4E).

Leaf morphology, morphometry, and flow cytometry The OE1 line had a larger leaf blade width and length compared with the wild-type line (Figure 4G). In contrast, the
RNAi line showed a shorter petiole length and a smaller leaf blade width, resulting in a decreased leaf size (Figure 4H).

Microscopic analysis of the leaf epidermis in the Arabidopsis OE and RNAi lines showed a population of giant cells in the transgenic lines (Figure 5A), which was not observed in the wild-type line (Figure 5B). Flow cytometry was used to screen DNA ploidy levels in first leaves from 

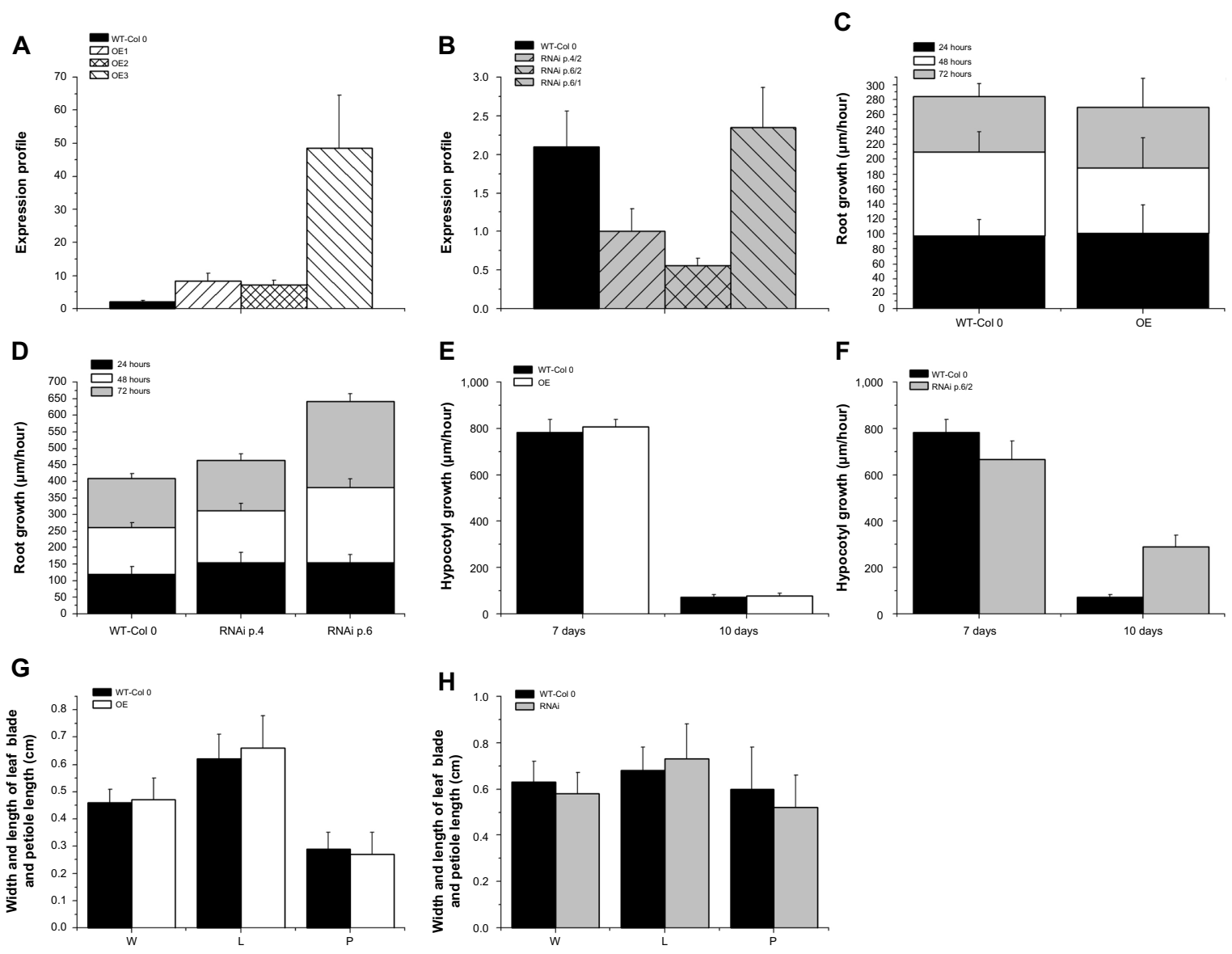

Figure 4 Expression and morphometric analyses of $A$. thaliana lines with OE or knockdown of cylin like F-box.

Notes: (A) F-box transcript level in homozygous OE Arabidopsis lines (OEI, OE2, OE3, and wild-type). (B) F-box transcript levels in homozygous RNAi Arabidopsis lines (RNAi 4/2, RNAi 6/I, RNAi 6/2, and wild-type). (C) Root growth analysis of OE Arabidopsis line and wild-type line. (D) Root growth analysis of RNAi Arabidopsis lines and wild-type line. (E) Hypocotyl growth analysis of OEI Arabidopsis line and wild-type line. (F) Hypocotyl growth analysis of RNAi 6/2 Arabidopsis line and wild-type line. (G) Leaf growth size analysis of OE Arabidopsis line and wild-type line. $(\mathbf{H})$ Leaf growth size analysis of RNAi Arabidopsis line and wild-type line.

Abbreviations: OE, overexpression; RNAi, RNA interference; WT, wild-type.

21-day-old plants from the OE and RNAi lines (Figure 6A). A significantly higher level of $16 \mathrm{C}$ cells was observed in leaves from the $\mathrm{OE}$ lines when compared with the wild-type line. In the RNAi 4/2 line, the ploidy levels were close to those of the control, with the exception of an almost doubled number of $16 \mathrm{C}$ nuclei. The RNAi 6/2 line showed a nearly doubled number of $4 \mathrm{C}$ cells.

To assess the relationship between DNA ploidy level and leaf morphology, several leaf parameters (leaf size, epidermal cell number, and epidermal cell size) were evaluated (Figure 6B-D). Our data indicated a greater leaf area in the $\mathrm{OE} 1$ line and a significantly smaller leaf area in the RNAi 6/2 line when compared with the wild-type line (Figure 6B). The average number of leaf epidermal cells in the $\mathrm{OE}$ lines was similar to the control (Figure 6C); however, the cells were larger than the wild-type cells (Figure 6D). Smaller leaf areas and fewer epidermal cell numbers were recorded in the RNAi lines; however, the size of the epidermal cells was markedly increased compared with the control and $\mathrm{OE}$ lines (Figure 6C and D).

\section{Silique morphology}

Statistical analysis of silique parameters showed a significantly $(P \leq 0.01)$ reduced silique length in the OE1 line when compared with the wild-type line (Figure 7A), with no significant difference in silique width (Figure 7C). No significant difference was found in silique length (Figure 7B) or width (Figure 7D) in the RNAi 6/2 line when compared with the control.

\section{Knockdown of F-box allows accumulation of CYCBI; I during G2/M phase}

Root tips from OE1, RNAi 6/2, and wild-type plants were synchronized in medium containing $1 \mathrm{mM}$ hydroxyurea 

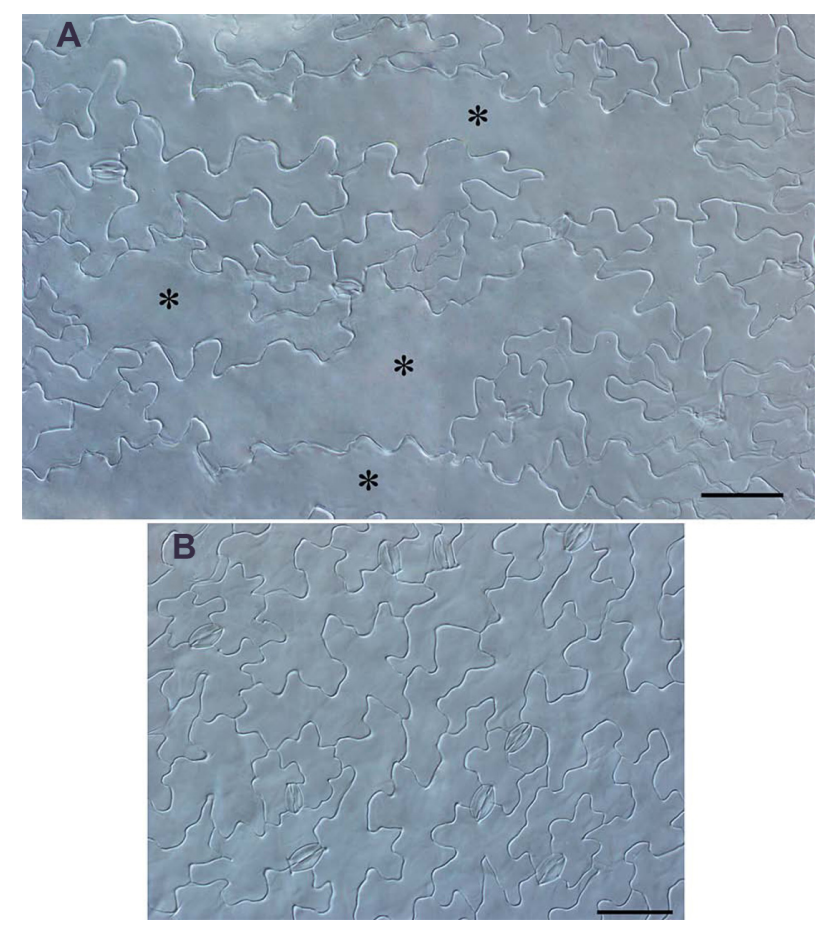

Figure $\mathbf{5}$ Light micrographs of leaf epidermis of Arabidopsis thaliana plants. Notes: Overexpression of F-box (A) and wild-type plants (B). Giant cells are marked with *. Scale bar $50 \mu \mathrm{m}$.

\section{A}

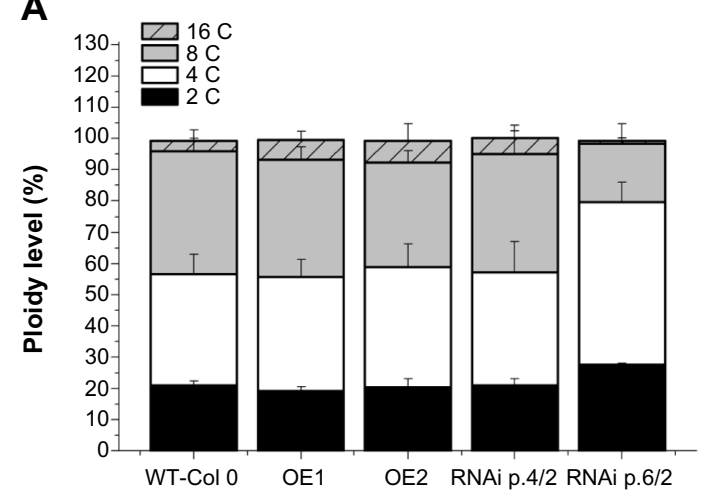

C

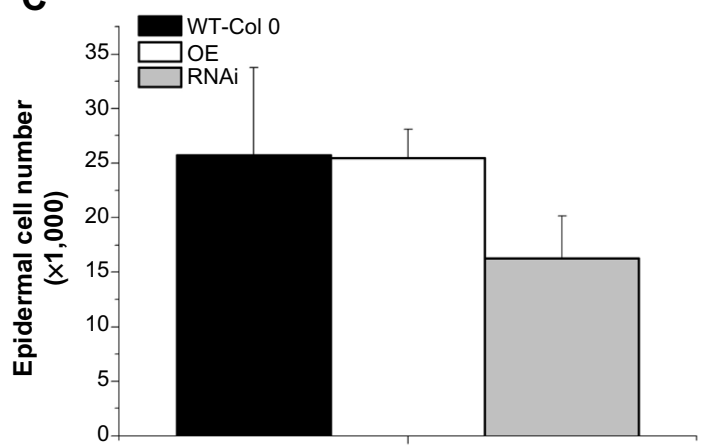

using a previously described method for root tip synchronization..$^{30}$ After 14 hours of synchronization, corresponding to $\mathrm{G} 2 / \mathrm{M}$ phase, the root tips were harvested. Data from the co-expression list of the Arabidopsis ortholog gene (ATTED version 6.0) prompted us to investigate whether F-box might play a role during G2/M transition. We selected $C Y C B 1 ; 1$ as a marker gene for the $\mathrm{G} 2 / \mathrm{M}$ phase of the cell cycle, as well as it is coexpressed gene from the ATTED list.

Transcript levels of the selected cell cycle marker gene were quantified using quantitative RT-PCR. Analysis of gene expression showed that F-box knockdown (RNAi 6/2) led to the accumulation of CYCB $1 ; 1$ transcripts. In contrast, the CYCB1;1 transcript level in the OE1 line was lower than in the control. These data imply that CYCB1;1 could be a target for degradation by the SCF complex, of which the investigated F-box protein is a component (Figure 8).

\section{Discussion}

In the course of the FP6 Grain Legumes Integrated Project, the AgroBioInstitute participated in the WP 5.2 and together with the other partners developed a large-scale Tnt 1 mutant

\section{B}
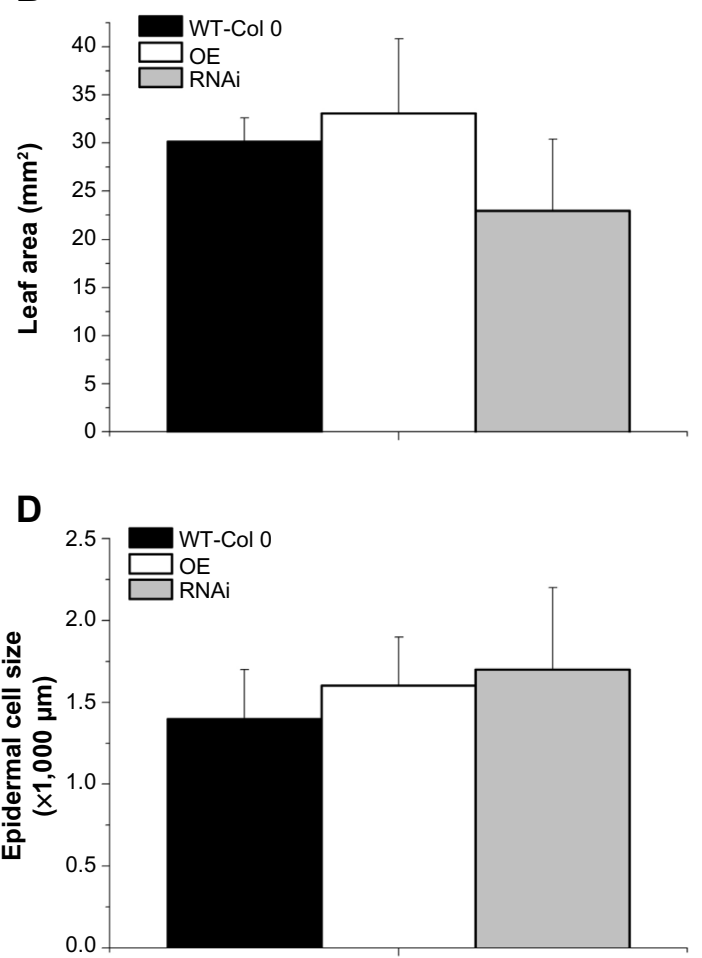

Figure 6 Flow cytometry and morphometric analyses of Arabidopsis thaliana lines with OE or knockdown of cylin like F-box.

Notes: (A) DNA ploidy level in leaves from wild-type, OE, and RNAi lines of Arabidopsis thaliana. (B) Morphometric measurements for leaf area. Data represent the mean \pm standard deviation $(n \geq 12)$. (C) Leaf cell number. Data represent the mean \pm standard deviation $(n \geq 12)$. (D) Average abaxial epidermal cell size. Data represent the mean \pm standard deviation $(n \geq \mid 2)$.

Abbreviations: OE, overexpression; RNAi, RNA interference; WT, wild-type. 
A

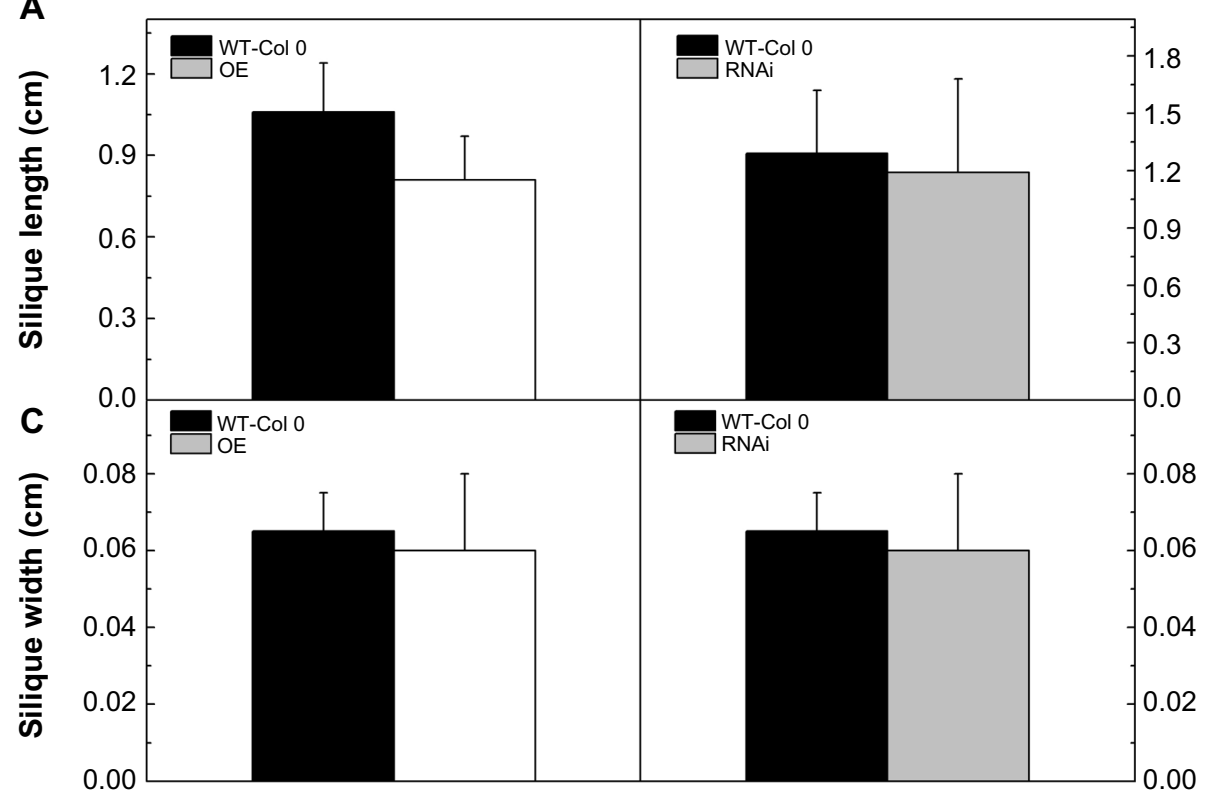

B

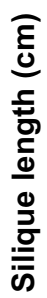

D

$\widehat{\varepsilon}$
0
$\frac{5}{0}$
$\frac{0}{3}$
$\frac{0}{\overline{0}}$
$\frac{\bar{\sigma}}{\bar{\omega}}$

Figure 7 Analysis of silique parameters for OEI, RNAi 6/2, and Col-0.

Notes: (A) Mean silique length in OE line and WT line. (B) Mean silique length in RNAi line and WT line. (C) Mean silique width in OE line and WT line. (D) Mean silique width in RNAi line and WT line.

Abbreviations: OE, overexpression; RNAi, RNA interference; WT, wild-type.

collection of M. truncatula. It was established that Tnt 1 insertions are stable and genetically independent. Some of these insertional mutants were investigated on the basis of forward and reverse genetic tools as part of the IFCOSMO (Integrated functional and comparative genomics studies on the model legumes M. truncatula and L. japonicus) project.

The plant genomic region that borders Tnt1 (flanking sequence tag) were used for identification of a mutant line (So 5945A) from the AgroBioInstitute collection. ${ }^{31,32}$ This line were selected because of the location of the flanking sequence tags in the coding sequence of important genes,

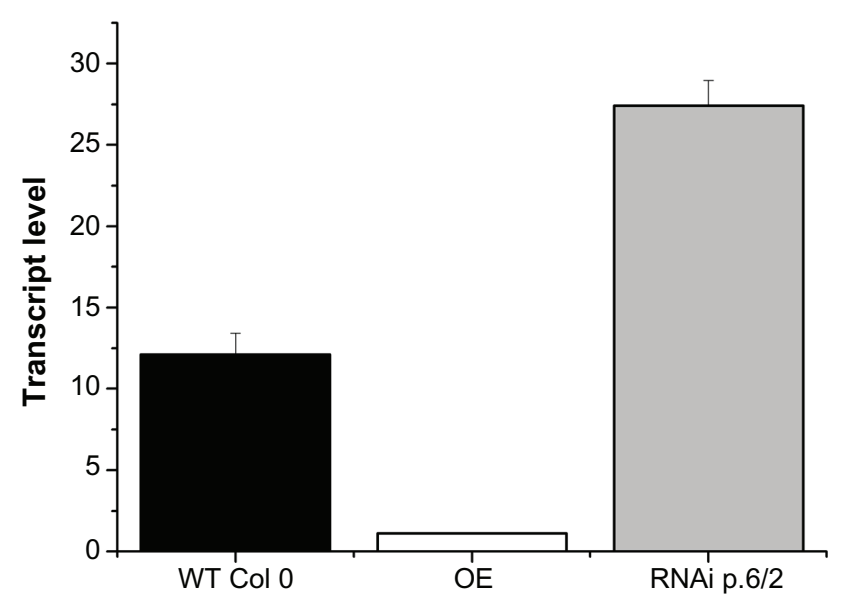

Figure 8 Transcript levels of the G2/M-marker gene CYCBI; I in the OE and RNAi Arabidopsis lines, and wild-type after 14 hours of treatment with I mM hydroxyurea. Abbreviations: OE, overexpression; RNAi, RNA interference; WT, wild-type. and one of them corresponds to a cyclin-like F-box protein (line 5945A insertion 7). This gene was selected for further molecular and functional investigations.

Histochemical, morphological, and transcriptional analyses combined with flow cytometry and histochemistry confirmed participation of the investigated F-box gene in plant growth and development, and during the processes of indirect somatic embryogenesis and symbiotic nodulation, and presumably in the cell cycle.

Expression of ASK and F-Box (FBX) proteins has previously been demonstrated in different plant organs including the cotyledons, shoot apical meristem, inflorescence, flower, node, cauline leaf, root, root tip, primary root, root epidermis, pericycle, shoot apex, pistil, pollen, anther, hypocotyl, stele, petiole, sperm cell, protoplast, guard cell protoplast, suspensor, rosette, and juvenile leaf. ${ }^{33}$ Our data confirmed these observations, showing expression of the F-box gene in all plant organs and tissues consisting of actively dividing cells, and during the stages of somatic embryogenesis, thus supporting the role of F-box in the growth and development of the three studied model plants (Figures 1-3). In $L$. japonicas transcriptional reporter lines, F-box expression was detected in the nodule vasculature (Figure 2C), but was not observed in the nodules of M. truncatula. This difference may be related to the type of nodules formed, ie, indeterminate in M. truncatula vs determinate in L. japonicus. Determinate nodules contain a relatively homogenous 
population of nitrogen-fixing bacteroids, as differentiation of the infected cells occurs simultaneously, followed by a senescence phase. In indeterminate nodules, nitrogen-fixing bacteroids continue their cell division activity, giving rise to a gradient of developmental stages. These nodules have a less branched vascular system than determinate nodules. ${ }^{34}$

In our study, gain and loss of function of the F-box gene led to multiple defects in plant development and in the plant cell cycle. We were able to observe variations in a number of plant morphology characteristics, including root (Figure 4C and D) and hypocotyl (Figure 4E and F) growth, leaf (Figure 4G and $\mathrm{H}$ ) and silique morphology (width and length of the leaf blade, length of the petiole, width and length of the siliques; Figure 7), DNA ploidy level (Figure 6A), and leaf parameters (leaf area, number of epidermal cells, epidermal cell size; Figure 6B-D). Another F-box protein, AFB4, plays a crucial role in plant growth and development, with $a f b 4$ mutants showing a pleiotropic phenotype, such as strongly reduced primary root growth, fewer lateral roots, very short hypocotyls, increased leaf thickness, and noticeably delayed flowering time. ${ }^{35}$ These data confirm the importance of the F-box protein as a developmental regulator and indicate its stability as an essential factor in regulation of SCF complex activity. The SCF complex is one of the well-studied members of the ubiquitin protein ligase E3 family, and regulates many processes, including the cell cycle, floral development, the circadian clock, and responses to plant growth regulators. ${ }^{36}$ The results presented here are consistent with previous reports indicating that F-box domain-containing protein is related to the cell cycle and has a modified gene expression level in mutant lines. ${ }^{37}$ One of the principal distinguishing characteristics of the investigated OE lines was a slower rate of root growth, whereas the RNAi lines showed a more rapid root growth rate when compared with the wild-type line.

Obvious changes in leaf morphology were detected, manifested by a larger leaf size (Figure 6B) and a greater length of the leaf blade in the OE lines (Figure 4G), and a smaller leaf size (Figure 6B), decreased epidermal cell number (Figure 6C), and increased cell size in the RNAi lines (Figure 6D). Light microscopy observations showed that the OE and RNAi lines had larger leaf epidermal cells (Figure 5A) when compared with the wild-type line (Figure 5B). However, in the $\mathrm{OE}$ lines, the number of epidermal cells was similar to that in the control, but less pronounced in RNAi lines. These analyses suggested the occurrence of the phenomenon of endoreduplication in the leaf cells of transgenic plants with F-box overexpression and downregulation. Endoreduplication involves one or several DNA replication rounds without mitosis or cytokinesis, resulting in an increment of the cell ploidy level. ${ }^{38}$ The endoreduplication process is closely correlated with epidermal cell size and number and with leaf area. A key element of plant morphogenesis is the correct balance between cell size and cell division. ${ }^{39}$ According to the model for cell size control, cells divide when they have reached the minimum cell size, the minimum cell size contributes to activation of the cell cycle checkpoints, and tissue-specific size controls are typical for cell development. ${ }^{40}$ In agreement with this model, we observed giant cells in the leaf epidermis of Arabidopsis transgenic lines (Figure 5A). This is consistent with the suggestion that disturbance of the studied F-box gene affects the timing of cell differentiation and F-box proteins can hamper SKP1 function, and consequently to decrease the function of the SCF complex. DNA endoreduplication often coincides with the initiation of cell differentiation in animals and plants. ${ }^{41}$ Thus, the F-box gene can affect the cell cycle and participate in the control of cell proliferation and differentiation.

In addition, we investigated the transcriptional response of the $\mathrm{G} 2 / \mathrm{M}$ phase cell cycle marker gene in background of OE, RNAi lines, and wild-type of synchronized of Arabidopsis root tips synchronized system. Our experiments showed that the $\mathrm{G} 2 / \mathrm{M}$-cell cycle phase marker CYCB1;1 reached maximum induction at 14 hours after treatment with $1 \mathrm{mM}$ hydroxyurea in RNAi plants (Figure 8). From the observed transcript profile, we established the absence of transcript accumulation in the OE lines and a higher level of CYCB1;1 transcript accumulation in the RNAi lines. We proposed that the investigated F-box protein, as a part of the SCF complex, probably not directly but through other target, contributes to the degradation of CYCB1;1. Additional analyses of protein levels are needed to identify the main ubiquitination target/s of the cyclin-like F-box protein and confirm the proposed function of this protein in control of the cell cycle. Most of the published data indicate that two E3 ubiquitin-ligase complexes control the SCF-related complexes and the anaphase-promoting complex/cyclosome, which operate at the G1-to-S transition and in the M-G1 phases plant cell cycle. ${ }^{42} \mathrm{~B}$-type cyclins that regulate the G2-to-M transition and progression through mitosis are targeted by the anaphase-promoting complex/cyclosome for destruction. ${ }^{43}$ Our primary results are not consistent with these findings. Further studies are required to clarify the detailed mechanisms underlying F-box-mediated regulation of the cell cycle. 


\section{Conclusion}

Based on the generated transgenic lines of the model species M. truncatula, L. japonicus, and A. thaliana and following expression of GUS and GFP reporters, we confirmed expression of the F-box gene in all plant organs and actively dividing tissues, demonstrating its important role in plant cell growth and development and during the processes of indirect somatic embryogenesis and symbiotic nodulation. Our working hypothesis that the studied F-box interacts with the $\mathrm{G} 2 / \mathrm{M}$-phase marker gene $C Y C B 1 ; 1$ was confirmed by accumulation of transcripts in the knockdown line and suggested a possible role of F-box in the cell cycle.

\section{Acknowledgments}

This study was supported by a grant from the National Science Fund at the Ministry of Education and Science of the Republic of Bulgaria (project DO 02-268, IFCOSMO). Part of this research was carried out at the Department of Plant Systems Biology, Ghent, Belgium, and was supported by an EMBO fellowship to AI.

\section{Disclosure}

The authors report no conflicts of interest in this work.

\section{References}

1. Vierstra RD. The ubiquitin-26S proteasome system at the nexus of plant biology. Nat Rev Mol Cell Biol. 2009;10:385-397.

2. Stone SL, Callis J. Ubiquitin ligases mediate growth and development by promoting protein death. Curr Opin Plant Biol. 2007;10:624-632.

3. Gagne JM, Downes BP, Shiu S-H, Durski AM, Vierstra RD. The F-box subunit of the SCF E3 complex is encoded by a diverse superfamily of genes in Arabidopsis. Proc Natl Acad Sci U S A. 2002;99: 11519-11524.

4. Zheng N, Schulman BA, Song L, et al. Structure of the Cul1-Rbx1Skp1-F box Skp2 SCF ubiquitin ligase complex. Nature. 2002;416: 703-709.

5. Cardozo T, Pagano M. The SCF ubiquitin ligase: insights into a molecular machine. Nat Rev Mol Cell Biol. 2004;5:739-751.

6. Risseeuw EP, Daskalchuk TE, Banks TW, et al. Protein interaction analysis of SCF ubiquitin E3 ligase subunits from Arabidopsis. Plant J. 2003;34:753-767.

7. Kuroda H, Takahashi N, Shimada H, Seki M, Shinozaki K, Matsui M. Classification and expression analysis of Arabidopsis FBX-containing protein genes. Plant Cell Physiol. 2002;43:1073-1085.

8. Hua Z, Zou C, Shiu SH, Vierstra RD. Phylogenetic comparison of F-box (FBX) gene superfamily within the plant kingdom reveals divergent evolutionary histories indicative of genomic drift. PLoS One. 2011;6:e16219.

9. Skaar JR, Pagan JK, Pagano M. SnapShot: F box proteins I. Cell. 2009;137:1160-1160. e1.

10. Ou CY, Pi H, Chien CT. Control of protein degradation by E3 ubiquitin ligases in Drosophila eye development. Trends Genet. 2003;19:382-389

11. Yang X, Kalluri UC, Jawdy S, et al. The F-box gene family is expanded in herbaceous annual plants relative to woody perennial plants. Plant Physiol. 2008;148:1189-1200.
12. Woo HR, Chung KM, Park JH, et al. ORE9, an F-box protein that regulates leaf senescence in Arabidopsis. Plant Cell. 2001;13:1779-1790.

13. Stirnberg P, Furner IJ, Leyser HMO. MAX2 participates in an SCF complex which acts locally at the node to suppress shoot branching. Plant J. 2007;50:80-94.

14. Imaizumi T, Kay S. Photoperiodic control of flowering: not only by coincidence. Trends Plant Sci. 2006;11:11.

15. Chae E, Tan QK, Hill TA, Irish VF. An Arabidopsis F-box protein acts as a transcriptional co-factor to regulate floral development. Development. 2008;135:1235-1245.

16. Guo H, Ecker JR. Plant responses to ethylene gas are mediated by $\mathrm{SCF}(\mathrm{EBF} 1 / \mathrm{EBF}$ )-dependent proteolysis of EIN3 transcription factor. Cell. 2003;115:667-677.

17. Dill A, Thomas SG, Hu J, Steber CM, Sun TP. The Arabidopsis F-box protein SLEEPY1 targets gibberellin signaling repressors for gibberellin-induced degradation. Plant Cell. 2004;16:1392-1405.

18. Binder BM, Walker JM, Gagné JM, et al. The Arabidopsis EIN3 binding F-box proteins EBF1 and EBF2 have distinct but overlapping roles in ethylene signaling. Plant Cell. 2007;19:509-552.

19. Han L, Mason M, Risseeuw EP, Crosby WL, Somers DE. Formation of an SCF (ZTL) complex is required for proper regulation of circadian timing. Plant J. 2004;40:291-301.

20. Kim HS, Delaney TP. Arabidopsis SON1 is an F-box protein that regulates a novel induced defense response independent of both salicylic acid and systemic acquired resistance. Plant Cell. 2002;14:1469-1482.

21. Karimi M, Bleys A, Vanderhaeghen R, Hilson P. Building blocks for plant gene assembly. Plant Physiol. 2007;145:1183-1191.

22. Limpens E, Ramos J, Franken C, et al. RNA interference in Agrobacterium rhizogenes-transformed roots of Arabidopsis and Medicago truncatula. J Exp Bot. 2004;55:983-992.

23. Nolan KE, Rose RJ, Gorst JR. Regeneration of Medicago truncatula from tissue culture: increased somatic embryogenesis using explants from regenerated plants. Plant Cell Rep. 1989;8:278-281.

24. Murashige T, Skoog F. A revised medium for rapid growth and bio assays with tobacco tissue cultures. Physiol Plant. 1962;15:473-497.

25. d'Erfurth I, Cosson V, Eschstruth A, Lucas H, Kondorosi A, Ratet P. Efficient transposition of the Tnt 1 tobacco retrotransposon in the model legume Medicago truncatula. Plant J. 2003;34:95-106.

26. Chabaud M, Larsonneau C, Marmouget C, Huguet $\mathrm{T}$. Transformation of barrel medics Medicago truncatula Gaetrn.) by Agrobacterium tumefaciens and regeneration via somatic embryogenesis of transgenic plants with the MtENOD 12 nodulin promoter fused to gus reporter gene. Plant Cell Rep. 1996;15:305-310.

27. Iantcheva A, Chabaud M, Cosson V, et al. Osmotic shock improves Tnt1 transposition frequency in Medicago truncatula cv Jemalong during in vitro regeneration. Plant Cell Rep. 2009;28:1563-1572.

28. Gamborg OL, Miller RA, Ojima O. Nutrient requirements of suspension cultures of soybean root cell. Exp Cell Res. 1968;50:151-158.

29. Clough SJ, Bent AF. Floral dip: a simplified method for Agrobacteriummediated transformation of Arabidopsis thaliana. Plant J. 1998;16: 735-743.

30. Cools T, Iantcheva A, Maes S. A replication stress-induced synchronization method for Arabidopsis thaliana root meristems. Plant $J$. 2010;64:718-727.

31. Revalska M, Vassileva V, Goormachtig S, Van Hautegem T, Ratet P, Iantcheva A. Recent progress in development of a Tnt1 functional genomics platform for the model legumes Medicago truncatula and Lotus japonicus in Bulgaria. Curr Genomics. 2011;12:147-152.

32. Boycheva I, Vassileva V, Iantcheva A. Histone acetyltransferases in plant development and plasticity. Curr Genomics. 2014;15:28-37.

33. Kuroda H, Yanagama Y, Takahashi N, Horii Y, Matsui M. A comprehensive analysis of interaction and localization of Arabidopsis SKP1LIKE (ASK) and F-box (FBX) proteins. PLoS One. 2012;7:e50009.

34. Ferguson BJ, Indrasumunar A, Hayashi S, et al. Molecular analysis of legume nodule development and autoregulation. $J$ Integr Plant Biol. 2010;52:61-76. 
35. Hu Z, Keceli MA, Piisila M, et al. F-box protein AFB4 plays a crucial role in plant growth, development and innate immunity. Cell Res. 2012;22:777-781.

36. del Pozo JC, Estelle M. F-box proteins and protein degradation: an emerging theme in cellular regulation. Plant Mol Biol. 2000;44: 123-128.

37. Liu Y, Wang F, Zhang H, He H, Ma L, Deng XW. Functional characterization of the Arabidopsis ubiquitin-specific protease gene family reveals specific role and redundancy of individual members in development. Plant J. 2008;55:844-856.

38. Massonnet C, Tisne S, Radziejwoski A, et al. New insights into the control of endoreduplication: endoreduplication could be driven by organ growth in Arabidopsis leaves. Plant Physiol. 2011;157:2044-2055.

39. Hemerly A, de Almeida Engler J, Bergounioux C, et al. Dominant negative mutants of the $\mathrm{Cdc} 2$ kinase gene uncouple cell division from iterative plant development. EMBO J. 1995;14:3925-3936.
40. Francis D. Cell size and organ development in higher plants. In: Francis D, Dudits D, Inze D, editors. Plant Cell Division. London, UK: Portland Press; 1998.

41. Ishida T, Adachi S, Yoshimura M, Shimizu K, Umeda M, Sugimoto K. Auxin modulates the transition from the mitotic cycle to the endocycle in Arabidopsis. Development. 2010;137:63-71.

42. Marrocco K, Bergdoll M, Achard P, Criqui MC, Genschik P. Selective proteolysis sets the tempo of the cell cycle. Curr Opin Plant Biol. 2010;13:631-639.

43. De Veylder L, Larkin JC, Schnittger A. Molecular control and function of endoreplication in development and physiology. Trends Plant Sci. 2011;16:624-634 


\section{Supplementary material}

Table SI List of primers used for the construction of vectors and RT quantitative polymerase chain reaction experiments

\begin{tabular}{ll}
\hline Mt-F gene promoter & TTGCGTTGGAAAATAAAC \\
Mt-R gene promoter & GATGAATTGATGTGAAGA \\
Mt-F gene overexpression & ATGCGTACAATCGAGCCTACA \\
Mt-R gene overexpression & TTCTATTCGAATTATCCCACGG \\
Mt-F gene inactivation & GTACAAAAAAGCAGGCGATGAGAT \\
& TTGCCGGTTCAG \\
Mt-R gene inactivation & GTACAAGAAAGCTGGGTAACTGGA \\
& AATCAGTACGAAATGC \\
Mt-Cyc F-box-forward & AGCAGTGCAAGCTGGATTTT \\
Mt-Cyc F-box-reverse & TCCCCCTCATTGACAGAAAC \\
At-Cyc F-box-forward & ATGGACTCTCTTCCTGATGCGAT \\
At-Cyc F-box-reverse & TCATTCTATATGAACAAGATGCTCGT \\
At-CycBI; I-forward & GAATGGAGGCCACGAGATTA \\
At-CycBI; I-reverse & CTGTGGTGGCCAAATTTCTT \\
At-actin2-forward & TGCCAATCTACGAGGGTTTC \\
At-actin2-reverse & TTCTCGATGGAAGAGCTGGT \\
At-ubiquitin-forward & GTCGACCCTTCACTTGGTGT \\
At-ubiquitin-reverse & CCTTGACGTTGTCAATGGTG \\
\hline
\end{tabular}

Abbreviation: RT, reverse transcription.
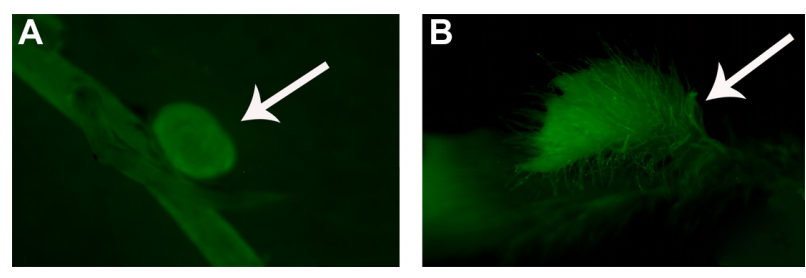

Figure SI Expression of the GFP reporter gene in transgenic plants.

Notes: (A) Nodule of Lotus japonicas. (B) Trichomes of young leaf in Medicago truncatula.
Research and Reports in Biology

\section{Publish your work in this journal}

Research and Reports in Biology is an international, peer-reviewed, open access journal publishing original research, reports, editorials, reviews and commentaries on all areas of biology including animal biology, biochemical biology, cell biology, ecological studies, evolutionary biology, molecular biology, plant science and botany. The

\section{Dovepress}

manuscript management system is completely online and includes a very quick and fair peer-review system. Visit http://www.dovepress. com/testimonials.php to read real quotes from published authors. 